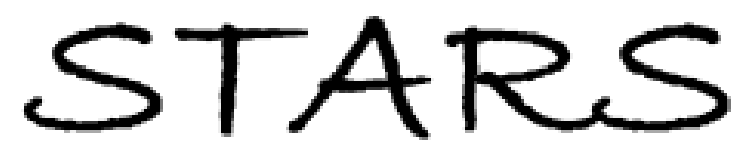

University of Central Florida

STARS

$1-1-2008$

\title{
The contributions of state attorneys general to homeland security matters
}

\author{
Gerald-Mark Breen \\ University of Central Florida \\ Jonathan Matusitz \\ University of Central Florida
}

Find similar works at: https://stars.library.ucf.edu/facultybib2000 University of Central Florida Libraries http://library.ucf.edu

This Article is brought to you for free and open access by the Faculty Bibliography at STARS. It has been accepted for inclusion in Faculty Bibliography 2000 s by an authorized administrator of STARS. For more information, please contact STARS@ucf.edu.

\section{Recommended Citation}

Breen, Gerald-Mark and Matusitz, Jonathan, "The contributions of state attorneys general to homeland security matters" (2008). Faculty Bibliography 2000s. 148.

https://stars.library.ucf.edu/facultybib2000/148

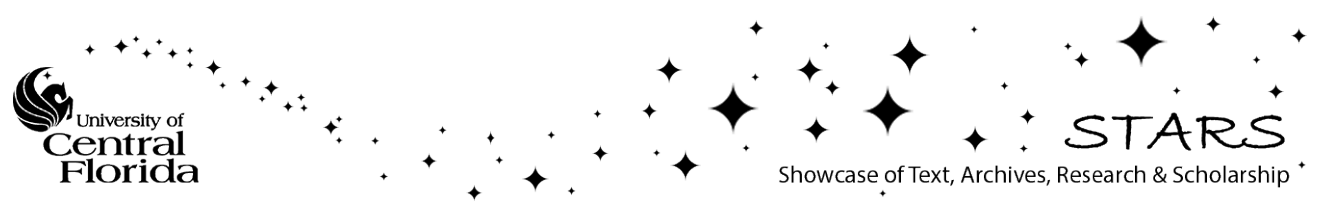




\section{Journal of Homeland Security and Emergency Management}

$\begin{array}{lll}\text { Volume 5, Issue } 1 & 2008 & \text { Article } 20\end{array}$

\section{The Contributions of State Attorneys General to Homeland Security Matters}

Gerald-Mark Breen, University of Central Florida Jonathan Matusitz, University of Central Florida

Recommended Citation:

Breen, Gerald-Mark and Matusitz, Jonathan (2008) "The Contributions of State Attorneys General to Homeland Security Matters," Journal of Homeland Security and Emergency Management: Vol. 5: Iss. 1, Article 20.

DOI: $10.2202 / 1547-7355.1421$ 


\title{
The Contributions of State Attorneys General to Homeland Security Matters
}

\author{
Gerald-Mark Breen and Jonathan Matusitz
}

\begin{abstract}
This study examines the roles of specific state attorneys general in the United States and assesses their degree of involvement in promoting and sustaining homeland security. This paper begins with a general overview of attorneys general, the National Association of Attorneys General (NAAG) and the Advisory Commission on Intergovernmental Relations (ACIR). Then, this paper provides a section on the contributions that the state attorneys general make to homeland security in the states of New Jersey, New York, and Florida. What comes afterwards is an assessment of the possibility of an increased effort and participation from these state governments to sustain homeland security. This paper ends with a discussion that also offers suggestions for future research.
\end{abstract}

KEYWORDS: attorneys general, government, homeland security, terrorism, United States

Author Notes: Gerald-Mark Breen, MA, is a research associate in the Department of Public Affairs at the University of Central Florida. He specializes in public relations, social policy, and conflict studies. Jonathan Matusitz, Ph.D., is an assistant professor in the Nicholson School of Communication at the University of Central Florida. His academic interests include conflict communication, new media studies, and health communication. 


\section{Introduction}

The purpose of this study is to examine the roles of selected state attorneys general in the United States and to determine their degree of involvement in promoting and sustaining homeland security. In addition, a further analysis of the general contributions that state attorneys general make in preventing terrorism and acts of violence on U.S. soil is conducted in an effort to reveal if their participation in counter-terrorism and crime prevention in their respective states is sufficient. Particularly, three major eastern U.S. states - that is, New Jersey, New York, and Florida (which happen to be eastern seaboard states, with high populations, and terrorist targets that threaten homeland security [Burke, 2006; Carter, 2002]) - are examined. The attorneys general who represent and are responsible for these states are described in terms of their active roles in sustaining homeland security through state and local government intervention.

This analysis is unique in that it is the first to examine the participation of state attorneys general in homeland security matters, especially those attorneys general working in susceptible, vulnerable states, and whether they are sufficiently or insufficiently functioning with respect to counter-terrorism and sustaining homeland security. As such, this paper begins with a general overview of (1) attorneys general, (2) the National Association of Attorneys General (NAAG), and (3) the Advisory Commission on Intergovernmental Relations (ACIR). Then, this paper provides a section on the contributions that the state attorneys general make to homeland security in the states of New Jersey, New York, and Florida. What comes afterwards is an assessment of the possibility of increased effort and participation from these state governments to sustain homeland security. This paper ends with a discussion that also offers suggestions for future research.

\section{Literature Review}

This section contains relevant information on state attorneys general, the origin of attorneys general, the National Association of Attorneys General (NAAG), and the Advisory Commission on Intergovernmental Relations (ACIR).

\section{State Attorneys General: Duties and Responsibilities}

A state attorney general is central and key within state governments. Given the status and label as the chief legal officer of the commonwealths, states, and territories of the United States of America, an attorney general typically functions as an "ultimate" counselor to his or her respective legislatures, as well as the many state and local organizations within the attorney general's particular state 
(Honssinger \& Lanni, 2005; Meyer, 2007; Provost, 2006). Because there are fifty states, which, altogether, present a wide variation among their respective jurisdictions (Griffin, 2004), stemming from constitutional and statutory mandates, the attorneys general usually have particular, distinctive rights and licenses to act in specific ways (according to where it is the attorney general is serving). Attorneys general normally possess the ability to release official opinions to state organizations. State attorneys general also typically serve as public advocates in legal arenas including antitrust and utility regulation (Greve, 2005), child enforcement (Lieberman \& Lester, 2003), and consumer protections (Waugh \& Sylves, 2002).

State attorneys general are responsible for suggesting new or amended legislation, enforcing environmental laws at the state and federal levels (American Veterinary Medical Association, 2006), representing state organizations prior to prosecutorial action in the state and federal courts (Federal Sentencing Reporter, 2006), directly dealing with criminal appellate cases and major criminal prosecutions within the state, filing claims and civil suits for various state organizations, serving in matters related to public interests (Alcohol \& Drug Abuse, 2004; Honssinger \& Lanni, 2005; Schmeling, 2003), such as charitable trust and solicitations (Kenan, 2006), and managing and implementing programs related to compensatory restitution for victims of crime (Provost, 2006).

In the nation's capitol (the District of Columbia), the Mayor appoints the Corporation Counsel, an entity whose authority and responsibilities run almost parallel to those of the attorneys general of the states and other territories (Bagli, 2007). In 43 out of the 50 states, state attorneys general are popularly elected. In Alaska, Hawaii, New Hampshire, New Jersey, and Wyoming, they are appointed by the governor. The governor also appoints attorneys general in the five jurisdictions of American Samoa, Guam, the Northern Mariana Islands, Puerto Rico and the Virgin Islands (Provost, 2006).

\section{Origin of Attorneys General}

The inception of attorneys general originated in $13^{\text {th }}$-century England, starting with a title referred to as the King's Attorney. At the onset of the American Revolution, the King's Attorney served as an advisor to royalty and to other government organizations. As the United States of America became distinct and established, the original colonies, now states (and various territories), were finally at liberty to devise their own procedures and common law (Parsons, 1997). The post of Attorney General was invented in 1789 (Kenan, 2006). Hence, with the emergence of the U.S., attorneys general were conceived and were assigned specific roles for the first states of the U.S. 


\section{The National Association of Attorneys General (NAAG)}

The National Association of Attorneys General (NAAG) is an organization whose mission is "to facilitate interaction among Attorneys General as peers" and "to facilitate the enhanced performance of Attorneys General and their staffs" (NAAG, 2008). Ensuring that all attorneys general in each state and territory are functioning optimally and adequately handling given responsibilities requires additional oversight and maintenance by an external entity. NAAG was established in 1907 (Greve, 2005; Kenan, 2006; Meyer, 2007; Schmeling, 2003). More specifically, NAAG's objectives are aimed at improving interaction among attorneys general as colleagues and cohorts, thus maximizing productivity of attorneys general and their administrative teams to effectively respond to arising state legal affairs. NAAG seeks to recognize and distribute critical information germane to the autonomy, span, organization and administration of the several offices held by the state attorneys general of the United States. Furthermore, NAAG produces and manages a friendly and community-oriented network encompassing state, chief legal officers, and jurisdictions by supplying a congregational venue for cooperation and knowledge development (Honssinger \& Lanni, 2005; Waugh \& Sylves, 2002).

Although NAAG significantly strives to attain harmony throughout attorneys general's offices, it also seeks to assist in the development of homeland security through heavy police involvement (Baker \& Baker, 2006). However, one of the most curious aspects of American policing is its decentralization; a vast proportion of U.S. police are dispersed across approximately 13,000 independent local police departments. NAAG and Homeland Security expert participants have noticed that there is in excess of 600,000 local police yet a mere 12,000 FBI agents scattered through U.S. states (Thatcher, 2005). Community protection, sponsored by attorney general offices and facilitated by NAAG, comprises all the actions involved in safeguarding a particular location against terrorism, including "target hardening, preventive patrol focused on likely targets of terrorist attack, response to threats against a specific target, and the development of emergency response plans" (Thatcher, 2005, p. 637). Based on this information, the United States can optimize its capacity to intercept and stop upcoming attacks by recruiting local police in the search of terrorist groups.

NAAG also supports unobstructed communication and collaboration regarding interstate legal affairs, as a means and effort to cultivate a more efficient legal system (Meyer, 2007), one quick to respond, for state citizens (Kenan, 2006). To facilitate advances within attorney general offices, NAAG provides guidance to those regarding important legal developments and budding trends transpiring within the states and federal government via information exchange, programs, and training. Clearly, NAAG assumes a specialized role in 
facilitating interaction among attorneys general as peers and attempts to optimize cooperative efforts between states' executive authorities.

NAAG has also taken a major part in working together with California and its attorney general. The California Anti-Terrorism Information Center (CATIC), established by the California Attorney General in cooperation with state and local law enforcement organizations, was founded following the terrorist attacks on World Trade Center and the Pentagon. CATIC serves to assist law enforcement personnel in California to achieve statewide intelligence to fight terrorism (Peschek, 2005). CATIC also allows for California law enforcement organizations to procure information on terrorist threats and activities throughout the state via a central record system (Sidel, 2004).

Advanced intelligence professionals produced by the Attorney General's Division of Law Enforcement assess information provided to the Center and determine any ramifications for the well-being and security of California residents (Peschek, 2005). Credible data must satisfy rigorous guidelines for intelligence collection, and civil rights protections are made accessible to authorized local and state law enforcement personnel as needed in order to defend general security of Californians from terrorist attacks (Eavanaugh, 2006).

\section{Advisory Commission on Intergovernmental Relations (ACIR)}

The Advisory Commission on Intergovernmental Relations (ACIR) is a fixed, freestanding, bipartisan organization established in 1959 to investigate and consider the intergovernmental relationships within the federal government and the United States' intergovernmental designs and strategies (Davies, 2007). ACIR is composed of twenty-six individual representatives who defend the interests of the intergovernmental partners with federal system (Cole, 2006). The interests deal with intergovernmental matters. ACIR is the only established, autonomous branch of the federal system where the opinions of the federal government's intergovernmental partners are openly circulated and publicized, and where complications, intricacies, and inefficiencies in the federal system's intergovernmental relationships are studied (Zimmerman, 2007).

Because state attorneys general are the chief law enforcement officers in their respective states, ACIR identifies how these state-level officials need to oversee and manage lower-level local government issues. As such, according to the mission as directly stated by ACIR itself, the goal is to "strengthen the American federal system and improve the ability of federal, state, and local governments to work together cooperatively, efficiently, and effectively" (ACIR, 2008). In the following section, specific U.S. states (FL, NJ, and NY) are examined with regard to their attorneys general and how these chief legal officers deal with homeland security in their respective states. Examining some of their 
current dealings with counter-terrorism and contributions to domestic, antiterrorism organizations can reveal what each of these attorneys general is sufficiently doing in the counter-terrorism, homeland security protection realm, in addition to what they are failing to do that raises the risk of attacks to homeland security in both their respective states and across the United States.

\section{Examining Specific States (NJ, NY, and FL): State Attorneys General and Their Homeland Security Contributions}

As we have previously mentioned, attorneys general are the chief law enforcement officers in their specific states. For this reason, they are key constituents who contribute significant thought, effort, and legal action in the counter-terrorism sphere (McWhorter, 2002). Nevertheless, why is it worthwhile to examine attorneys general in the context of counter-terrorism measures? First, it is important to recognize the seriousness and pervasiveness of terrorist attacks and their threats to homeland security (Kenan, 2006; Matusitz \& Breen, 2006). In this case, a diagram illustrating this seriousness needs to be provided for clarification. In Figure 1, from the U.S. Department of Justice (2006), a bar chart is provided to demonstrate terrorist attacks against and in the United States, from 1980 to 2005 .

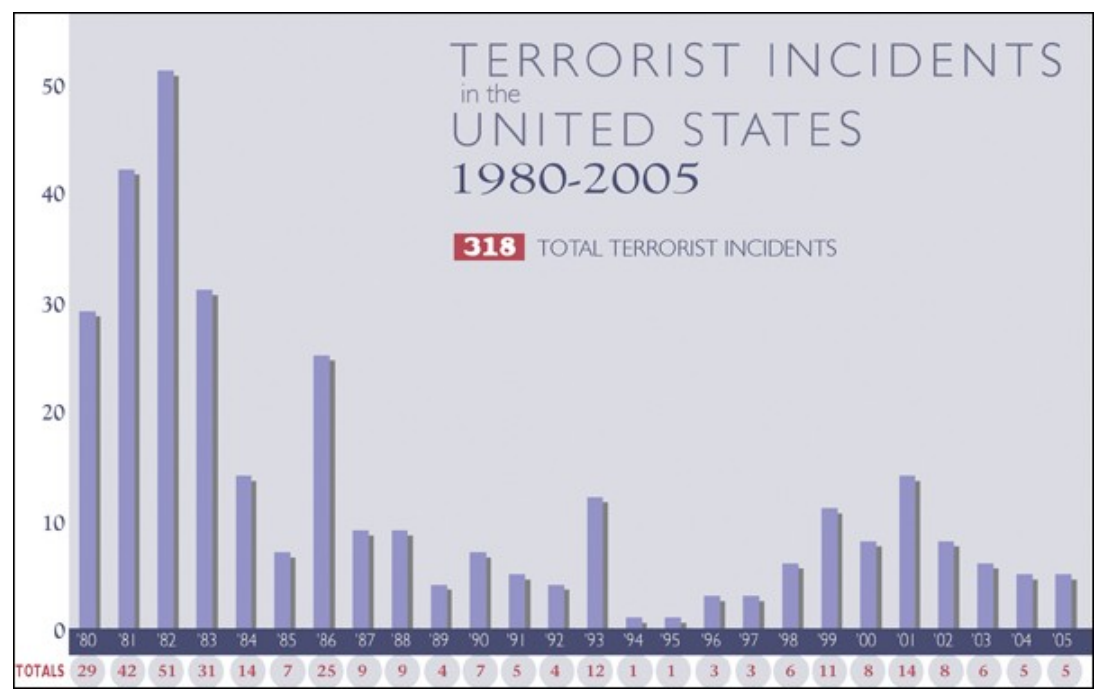

Figure 1: Terrorist incidents in the United States, 1980-2005 (U.S. Department of Justice, 2006)

It is crucial that attorneys general - particularly those who are positioned in states where terrorism is a serious threat - take appropriate actions with their 
partners and other state and local authorities to ensure a minimization of harm to homeland security. The United States is targeted for terrorism and political violence, and the attorneys general who work within specific states where terrorist attacks have been known to happen, or where they are likely to occur, need to address these matters to other state political and government figures and local authorities. Secondly, the United States is a country that has a low level of peace with a ranking of 96 (out of 121 countries). According to U.S. Department of State (2007), the higher the ranking (or number), the lower the state of peace of that country at the global level (see Figure 2 below). In addition, the United States holds a score of 2.317 , while Norway (the country reported to have the highest level of peace) holds a score of 1.357. Iraq, the least peaceful country of all, holds a score of 3.437. To simplify, this Global Peace Index shows that the United States is particularly prone to incurring acts of terrorism.

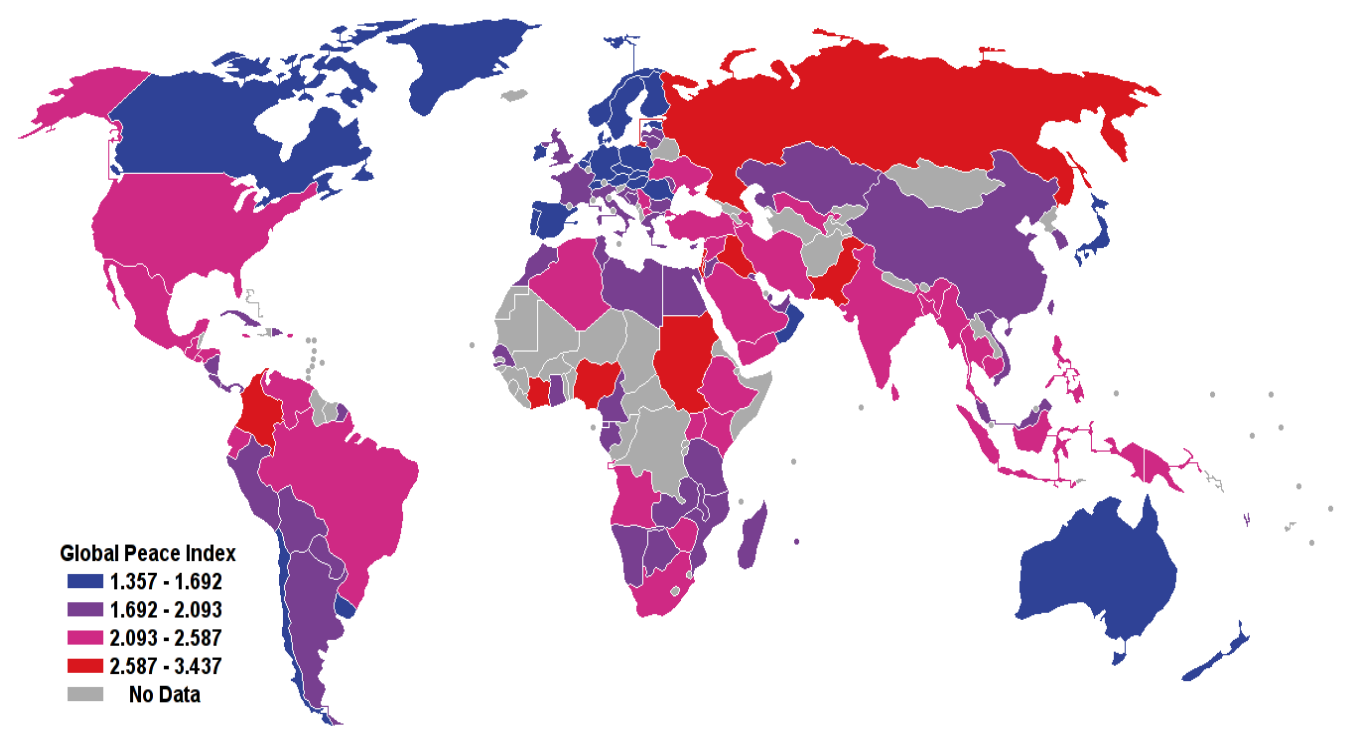

Figure 2: Global Peace Index (U.S. Department of State, 2007)

The goal of the Global Peace Index is to measure the position of each nation's and region's peacefulness relative to that of other nations worldwide. This index is managed and reported by The Economist (U.S. Department of State, 2007). Once attorneys general become aware of the above facts and statistics (as shown in Figures 1 and 2), actions can be taken by to enable a cooperative, collective effort between several local organizations within the states (Leone \& Anrig, 2007). The next sections will focus specifically on New Jersey, New York, and Florida. The reason these states were selected lies in the fact that they represent three eastern seaboard states with high populations susceptible to direct 
westbound attacks (Burke, 2006). Furthermore, conclusions generated by attorneys general in these states regarding terrorism preparedness can lead to a sharing of information to other state attorneys general toward a collective effort $v i s-\grave{a}$-vis homeland security and defense in the eastern maritime states.

New Jersey

The Attorney General of New Jersey serves as a constituent of the executive cabinet of the state. Appointed by the Governor of New Jersey, the state attorney general is an office that has limited terms. According to the New Jersey State Constitution, the Attorney General is expected to complete simultaneous service with the governor over a four-year term. The Attorney General in New Jersey also cannot be removed from office, save by impeachment. In 2004, New Jersey's Attorney General, Peter Harvey, announced that the U.S. Department of Homeland Security's Office for Domestic Preparedness (ODP) approved New Jersey's all-inclusive approach to allocate $\$ 87.4$ million dollars in homeland security funds (Gale, 2006; Laws, 2005; Tombs, 2006). At the very moment ODP dispensed the allocation, New Jersey and its Attorney General - in collaboration with its county and municipal associates - built a detailed a plan to ensure the homeland security funds were properly used. In March 2006, New Jersey Governor Corzine signed an executive order establishing a cabinet-level Office of Homeland Security and Preparedness in the state and selected a former White House National Security Council staff member to serve as its first director (Jones, 2006). In addition, former Governor James McGreevey (2004) stated the following in response to New Jersey and the state attorney general's advances in acquiring instruments for homeland security in that state:

New Jersey will continue to use available federal dollars to provide the greatest possible protection for our citizens. I am pleased that the Department of Homeland Security has responded to our requests and the requests of our Congressional delegation to factor risk into its grant allocations, at least in funding for our urban areas. But we will continue our efforts with our Congressional delegation to ensure that a State as densely populated with people and critical infrastructure as New Jersey receives funding commensurate with the risks it faces.

Also with respect to New Jersey ${ }^{1}$, Attorney General Harvey declared that the Department of Homeland Security (DHS) approved $\$ 55.4$ million in funds for

\footnotetext{
${ }^{1}$ For academics, researchers, practitioners, and legislators, the point of contact for the New Jersey Office of Homeland Security \& Preparedness is the URL
} 
first responders, law enforcement officers, and civilian volunteers (Tombs, 2006). An additional \$32 million was also appropriated from Urban Area Security Initiative (UASI) grants, enabling for a general improvement in security in the six-county greater Newark and Jersey City metropolitan regions (Gale, 2006).

In regards to the UASI grants, Attorney General Harvey praised Mayor James of Newark and Mayor Cunningham of Jersey City for recognizing the importance that New Jersey's training, preparation, and responsiveness must be regional, in that there can be no restrictions confining officials within city borders (Gale, 2006; Lechich, 2006). The attorney general must provide oversight to ensure the continuity of funding for a range of security enhancements intended to identify and prevent the activation of terrorist attacks and to boost response quality in the event that an attack befalls. Clearly, communication between first responders and the medical community is crucial to the success of this stateissued plan.

New Jersey has clearly taken several steps to enhance homeland security strategies and defense. The former Governor, McGreevey, pursued many measures to ensure sufficient funding for security projects. The New Jersey Attorney General, Harvey, also met with several important mayors throughout the state and authorized other law enforcement personnel to receive preparatory training to deal with counter-terrorism (Lechich, 2006). Harvey insisted that those who legitimately involve themselves in homeland security efforts or counterterrorism are compensated adequately when the participants exert themselves this realm. The Department of Homeland Security was responsive to New Jersey in making all these protections viable. At this point, it appears that New Jersey and its attorney general are working satisfactorily in their mission to sustain homeland security in general and New Jersey in particular.

New York

New York was the state to be historically hit with the massive terrorist attack widely known as 9/11. This attack led to the collapse of the Twin Towers in New York City and rendered enormous casualties. New York Attorney General, Andrew Cuomo, in cooperation with the National Sheriff's Association, the National Crime Prevention Council, and local law enforcement organizations, have also introduced and ensured the implementation of state initiatives to enhance homeland security (Lechich, 2006). Although the mundane practice commonly referred to as "Neighborhood Watch" is a typical plan across counties

http://www.njhomelandsecurity.gov/dsptf/dsptfhome.html. The mailing address is New Jersey, Office of Homeland Security \& Preparedness, P.O. Box 091, Trenton, NJ 08625 (609-584-4000). 
and cities, Neighborhood Watch is a major policy in New York ${ }^{2}$ (and its communities) to identify and suspect potential terrorists from threatening homeland security. Cuomo also directed a coalition of 400 mayors and law enforcement officials to confront and reduce gun violence, rendering a transformation in the methods in which gun manufacturers manage the distribution of guns. Additionally, criminal statutes have been put in place to deter and punish acts of terrorism, particularly the New York Penal Code $\S 490.25$ Crime of terrorism (New York Criminal Statutes and Rules, 2008).

It appears that New York is taking major actions with respect to preventing future acts of terrorism on their front. However, is Attorney General Cuomo correctly tackling this problem by cooperating with the National Sheriff's Association, the National Crime Prevention Council, and local law enforcement organizations by implementing practices aimed at reducing threats homeland security? Local agents from the Federal Bureau of Investigation, Department of Homeland Security, the Department of Defense, and military branches located in New York and in neighboring states need to engage forces toward this preventative objective. In line with how New Jersey operates in this respect, New York needs to advertise and implement a widespread training program for state law enforcement employees and other citizens who wish to contribute to this campaign against terrorism. Perhaps one solution is for New York's governor and attorney general to meet and coordinate with New Jersey's governor and attorney general to share ideas on how to deal with homeland security on New York's front. Since New York was the state to be hit hard by terrorists in the monumental September 11, 2001 attacks, New York needs to take every measure possible to optimize their homeland security. Such maximal protection to New York and the United States requires both a state and national intergovernmental convention that directly addresses these issues in New York.

\section{Florida}

The Florida Attorney General is an elected official and serves in this position for a term of four years in office, with a limit of two terms. These regulations are a sort of reflection of what is allowed if a U.S. President in terms of allowable time in office. In the state of Florida, Attorney General Bill McCollum, who was previously a member of the U.S. House of Representatives before he became an attorney general, has issued a number of policies designed to address violent crime and improve the state's security against terrorist threats (Henderson, 2007). Attorney General McCollum - both when he was a congressman and an attorney

${ }^{2}$ The point of contact for the New York State Office of Homeland Security is the URL http://www.security.state.ny.us/. The mailing address is Office of Homeland Security, State of New York, 633 Third Avenue, New York, NY 10017 (212-867-7060). 
general - developed, established, and participated in the U.S. House Task Force on Terrorism and Unconventional Warfare and has been acknowledged as a terrorism expert. Also affiliated with the responsibilities of Attorney General McCollum is the Florida Division of Emergency Management, which has aided in the development of various city-level groups to help prevent terrorist attacks and enhance homeland security (Gizzi, 2007). Community Emergency Response Teams are local or neighborhood groups that undergo significant instruction and preparation to enable them to identify, react to, and recuperate following a disaster or terrorist situation (Matusitz, 2007). Further, county, municipal, and state organizations cooperated to pinpoint specific susceptibilities and vulnerabilities that Florida possessed with respect to terrorism attacks.

In September 2004, in the court case of "US v. Adham Hassoun, Mohamed Youssef," a number of Middle-Eastern individuals, living in Broward County, Florida, engaged in an armed cause of terrorism activities by conspiring to advance violent jihad, including the support of and the participation in armed confrontations in specific locations both on U.S. soil and overseas (U.S. v. Hassoun and Youssef, 2004). Later, Attorney General McCollum and the Florida State Legislature helped spawn and advance terrorism prevention and homeland security protection via the Florida Department of Law Enforcement (FDLE) (Bullock \& Haddow, 2006). The FDLE is now heavily involved in the management of domestic security issues and responses in Florida ${ }^{3}$, and is currently striving to develop a strong and successful association with federal offices in charge of maintaining domestic homeland security (Gizzi, 2007). Even though counter-terrorism efforts are an important priority of the federal government, the $9 / 11$ strikes made it evident that state and local governments must considerably contribute in preventing domestic terrorism and responding to future terrorist attacks, should they come to pass (Griffin, 2004).

The Attorney General has also facilitated the advent and implementation of the Regional Mutual Aid Response Capability, a statement that poses a systematic series of objectives (McEntire \& Myers, 2004). These include the following goals: (1) prevent, preempt, and deter acts of terrorism; (2) prepare for terrorism response missions; (3) protect Florida's citizens, visitors, and critical infrastructure; (4) respond in an immediate, effective, and coordinated manner (focused on the victims of the attack); and (5) recover quickly and restore our way of life following a terrorist act.

Evidently, Florida is proactive in its counter-terrorism actions, especially in light of the attorney general's role in initiating a cooperative effort from

3 The point of contact for the Florida Division of Emergency Management is the URL http://www.floridadisaster.org/bpr/EMTOOLS/Severe/terrorism.htm. The mailing address is Florida Division of Emergency Management, 2555 Shumard Oak Boulevard, Tallahassee, Florida 32399-2100 (850-413-9969). 
multiple organizations. Florida certainly has a strong force against threats to homeland security, much like New Jersey does. Yet, it does seem that New York is lagging behind these two other states. Perhaps New York can learn from the practices and innovative procedures implemented by New Jersey and Florida. Another pursuit to achieving optimal levels of security, by the Attorney General and Governor of Florida, could be to meet and coordinate with neighboring states, such as Georgia and the Carolinas, and exchange ideas on how to maximize homeland security in the southeastern coast of the United States. Also, further employing military branches alongside the coastal borders, including the Navy and Coast Guard, can help continue maintain vigilance toward any intruders who may be terrorists attempting to illegally enter the country for destructive purposes.

\section{Discussion and Future Directions}

What this analysis has demonstrated is that attorneys general play a major role in pursuing and maintaining homeland security. They accomplish this, particularly, through their various state, regional, and local responsibilities and via organizations such as the National Association of Attorneys General (NAAG) and the Advisory Commission on Intergovernmental Relations (ACIR). Without the key actions taken by the attorney general in states such as New Jersey, New York, Florida (and even California), law enforcement personnel and organizations both within the states and nationally could not engage their efforts in an absolutely necessary collaborative endeavor to prevent terrorists and other devastating actors from intruding or causing damage to our states and nation. Because attorneys general represent chief law enforcement officers, and are, in a sense, presidents of legal enforcement in their states or territories, they are held primarily responsible and accountable to their public for ensuring safety to their states, as well as the economic infrastructure and office buildings where citizens earn an income and contribute to the health of business at both state and local levels.

Specifically, attorneys general in the aforesaid vulnerable states have achieved a reasonable degree of coordination with other state and local government groups in this battle toward counter-terrorism. New York and its attorney general seem to have shown the weakest links with other state and local organizations in this effort, among the states examined, and need to elevate and increase their associations with additional mayors, members of the Department of Homeland Security and the Department of Defense, other states (New Jersey, Florida, California, etc.) to exchange strategies for enhancing homeland security, and perhaps create additional presence of Coast Guard and related military branches patrolling the surrounding waters. Whatever actions are taken, the attorney general in New York needs to reexamine all the resources that are being 
dedicated toward counter-terrorism and determine where additional resources need to be allocated.

State attorneys general, in short, need to re-assess their duties in matters related to protecting homeland security. They have the ability to communicate with the governors of their states, and other major local, state, and national government groups to coordinate a full-fledged campaign to target violence and terrorism across the nation. Through free-flowing communication, interorganizational and intergovernmental cooperation, and the optimization of all strategic areas related to homeland security, a likely outcome from these efforts should render increased safety and protection across the United States and the rest of the world.

For future research, it might prove interesting to examine whether state attorneys general are adequately addressing the threats of cyberterrorism - not just the terrorism threat - in the context of homeland security. Cyberterrorism is the "creation of weapons (malicious software and electromagnetic weapons) to destroy data in cyberspace in order to cause a disruption in the physical world" (Matusitz, 2005, p. 138). Cyberterrorism also refers to the deliberate employment of disruptive actions against computers, networks, and the Internet in order to inflict harm or foster ideological, political, or similar goals, or to intimidate any individual in the promotion of those goals (Arquilla, Ronfeldt, \& Zanini, 1999; Conway, 2002). State attorneys general need to be aware of the legitimate and comparable threat that cyberterrorism poses to state and local governmental infrastructures (see Dunnigan, 2003) as they, too, rely heavily on elements and frameworks that could be the targets of cyberterrorism.

Lastly, it would be curious to investigate, on a new note, the following questions for practitioners and scholars within government, political science, social policy, and public administration spheres: Do U.S. states need to establish additional counter-terrorism organizations - at the state, regional, or local levels of which state attorneys general are in charge? What are the best steps to ensure that homeland security or counter-terrorism measures achieve optimal efficiency? Should it start at the local level, then gradually proceed to the national level, or should the process be reversed? Are state attorneys general actually the most appropriate officials to supervise and coordinate intergovernmental relationships regarding homeland security matters? Although such topics may not have been directly or indirectly addressed, both in terms of positives and negatives, for the purpose of investigation, a logical next step would be to explore these areas in greater detail.

No matter what, if the United States seeks to strengthen the current situation of homeland security and be better prepared to respond to potential threats or attacks, then the role of state attorneys general needs to be pivotal in 
their mission to sustain the broad effort - by all levels of government; state, regional, and local - to protect the United States, both internally and externally.

\section{References}

Advisory Commission on Intergovernmental Relations (2008). Retrieved March 16, 2008 from http://www.library.unt.edu/gpo/acir/Default.html.

Arquilla, J., Ronfeldt, D., \& Zanini, M. (1999). Networks, netwar and information-age terrorism. In I. O. Lesser, B. Hoffman, J. Arquilla, D. F. Ronfeldt, M. Zanini, \& B. M. Jenkins (Eds.), Countering the new terrorism (pp. 39-88). Santa Monica: RAND.

Attorney General guidelines for victim and witness assistance (2006). Federal Sentencing Reporter, 19(1), 78-82.

Bagli, C. V. (2007, September 19). To some, hiring of top criminal lawyer suggests worries in Deutsche Bank case. The New York Times, p. B3.

Baker, N. V., \& Baker, N. V. (2006). General Ashcroft: Attorney at war. Lawrence, KS: University Press of Kansas.

Bullock, J., \& Haddow, G. (2006). Introduction to homeland security. Boston: Butterworth-Heinemann.

Burke, R. (2006). Counter-terrorism for emergency responders. Boca Raton, FL: CRC Press.

Carter, A. B. (2002). The architecture of government in the face of terrorism. International Security, 26(3), 5-23.

Cole, R. L. (2006). Public opinion on U.S. federal and intergovernmental issues in 2006: continuity and change (Advisory Commission on Intergovernmental Relations' report). Publius, 36(3), p. 443.

Conway, M. (2002). What is cyberterrorism? Current History, 2, 436-440.

Davies, G. (2007). See government grow: Education politics from Johnson to Reagan. Lawrence, KS: University Press of Kansas.

Dunnigan, J. F. (2003). The next war zone: Confronting the global threat of cyberterrorism. New York: Citadel Press.

Eavanaugh, T. (2006). March of the moles. Reason, 38(7), 8-9.

Gale, D. E. (2006). Greater New Jersey: Living in the shadow of Gotham. Philadelphia: University of Pennsylvania Press.

Gizzi, J. (2007). Rudy tough on immigration issue, claims Florida Attorney General. Human Events, 63(22), p. 5.

Greve, M. S. (2005). Cartel Federalism? Antitrust enforcement by state attorneys general. University of Chicago Law Review, 72(1), 99-122.

Griffin, D. R. (2004). The 9/11 Commission report: Omissions and distortions. Ithaca: Olive Branch Press. 
Henderson, L. (2007). Under investigation: The inside story of the Florida attorney general's investigation of Wilhelmina Scouting network, the largest model and talent scam in America. New York: Coyote Ridge Publishing.

Honssinger, C., \& Lanni, R. (2005). The emerging role of state attorneys general in public health emergencies. Journal of Law, Medicine, \& Ethics, 33(4), 115-118.

Jones, R. L. (2006, March 17). Homeland Security becomes a cabinet office in New Jersey. New York Times, p. D1.

Kenan, W. R. (2006). Break up the Presidency? Governors, state attorney generals, and lessons from the divided executive. Yale Law Journal, 115(9), 2446-2479.

Laws, J. (2005). Bulking up responders' readiness. Occupational Health \& Safety, $74(5)$, p. 4.

Lechich, A. (2006). A storm in the port: Keeping the port of New York and New Jersey open. Hanover: Dartmouth College Press.

Leone, R. C., \& Anrig, G., Jr. (2007). Liberty under attack: Reclaiming our freedoms in an age of terror. New York: PublicAffairs.

Lieberman, A. A., \& Lester, C. (2003). Social work practice with a difference: A literary approach. Boston: McGraw-Hill.

Louisiana attorney general launches HSUS investigation (2006). Journal of the American Veterinary Medical Association, 228(11), 1650-1652.

Matusitz, J. (2005). Cyberterrorism: How can American foreign policy be strengthened in the information age? American Foreign Policy Interests, 27(2), 137-147.

Matusitz, J. (2007). Terrorism preparedness for hospitals: Towards better interorganizational communication. The International Journal of Strategic Communication, 1(3), 169-189.

Matusitz, J., \& Breen, G. M. (2006). Negotiation tactics in organizations applied to hostage negotiation. Journal of Security Education, 2(1), 53-72.

McEntire, D. A., \& Myers, A. (2004). Preparing communities for disasters: Issues and processes for government readiness. Disaster Prevention and Management, 13(2), 140-152.

McWhorter, D. (2002). Carry me home - Birmingham, Alabama: The climactic battle of the Civil Rights revolution. New York: Simon \& Schuster.

Meyer, T. (2007). Federalism and Accountability: State Attorneys General, regulatory litigation, and the new Federalism. California Law Review, 95(3), 885-914.

National Association of Attorneys General (2008). Retrieved March 16, 2008, from http://www.naag.org/about naag.php.

New York Criminal Statutes and Rules (2008). New York: Matthew Bender. 
North Carolina attorney general outlines steps for fighting meth (2004). Alcoholism \& Drug Abuse Weekly, 16(6), p. 7.

Parsons, J. C. (1997). Eleanor of Castile: Queen and society in thirteenth-century England. Houndmills, England: Palgrave Macmillan.

Peschek, J. G. (2005). The politics of empire: War, terror, and hegemony. London: Routledge Press.

Provost, C. (2006). The politics of consumer protection: Explaining state attorney general participation in multi-state lawsuits. Political Research Quarterly, 59(4), 609-618.

Schmeling, T. A. (2003). Stag hunting with the state AG: Anti-tobacco litigation and the emergence of cooperation among state attorneys general. Law \& Policy, 25(4), 429-454.

Sidel, M. (2004). More secure, less free? Antiterrorism policy and civil liberties after September 11. Ann Arbor, MI: University of Michigan Press.

Thatcher, D. (2005). The local role in homeland security. Law \& Society Review, 39(3), 635-676.

Tombs, R. B. (2006). Policy review: Blocking public geospatial data access is not only a homeland security risk. URISA Journal, 16(2), 49-51.

U.S. Department of Justice (2006). Terrorism, 2002-2005. Washington D.C.: U.S. Department of Justice.

U.S. Department of State (2007). Global Peace Index. Washington D.C.: U.S. Department of State.

U.S. v. Hassoun and Youssef, No. 04-60001, 2004 U.S. Dist. Ct.

Waugh, W. L., \& Sylves, R. T. (2002). Organizing the war on terrorism. Public Administration Review, 62, 145-153.

Zimmerman, J. F. (2007). The silence of Congress: State taxation of interstate commerce. New York: State University of New York Press. 